UNRAM Law Review is licensed under a Creative Commons Attribution 4.0 International License, which permits unrestricted use, distribution, and reproduction in any medium, provided the original work is properly cited. p-ISSN: 2548-9267 | e-ISSN : 2549-2365, Open Access at : http://unramlawreview.unram.ac.id/index.php/ulr

\begin{tabular}{|c|c|c|c|c|}
\hline Volume & Issue & Page & April & p-ISSN: 2548-9267 \\
\hline 3 & 1 & $15-24$ & 2019 & e-ISSN : 2549-2365 \\
\hline
\end{tabular}

\title{
The Juridical Implication on Signature of a Notary or Official Land Deed on the Statement Certificate of Transfer of Rights of a Land and/ or Building or the Amendment of Bonding Agreement of Sale and Purchase of Land and/ or Building
}

\author{
Sumawati \\ Postgraduate on Master program of notary brawijaya university \\ Jl. MT. Haryono No. 169, Malang 65145, Indonesia \\ Email: sumawatiprasetyo@gmail.com \\ Tunggul Anshari Setia Negara \\ Postgraduate on Master program of notary brawijaya university \\ Jl. MT. Haryono No. 169, Malang 65145, Indonesia \\ Email: sumawatiprasetyo@gmail.com

\section{R. Imam Rahmat Safi'i} \\ Postgraduate on Master program of notary brawijaya university \\ Jl. MT. Haryono No. 169, Malang 65145, Indonesia \\ Email: rimamrahmats@ub.ac.id
}

\begin{abstract}
This research journal discusses legal issues relating to the legal implications of Notary Public or Land Deed Officials (PPAT) in the declaration of transfer of land and / or building rights or the amendment of sale and purchase agreement on land and building to be reviewed from Appendix II of the Regulation of the General Director of Tax No. PER18 / PJ / 2017. Based on Article 3 of the Regulation of General Director of Tax Number PER-18 / PJ / 2017 concerning Procedures of Research of Proof of Fulfillment of Tax Obligation of Income Tax on Transfer of Right to Land and / or Building and Sale and Purchase Agreement on land and / or building and its amendment, where the taxpayer or his / her proxy is required to submit a research request proof of the fulfillment of the obligation to deposit the income tax one of them by attaching the Statement of transfer of rights to the land and or building that has been filled completely and stamped, and a copy of proof of sale and / or receipt of cash in cash which has been signed by the party that transferred the right to the land. Therefore, the Notary or Officer of the Deed of Land (PPAT) as the official authorized to make the deed related to the transfer of land and I or building rights are required to participate in knowing and signing the Statement of Transfer of Land and / or Land Rights. Pursuant to this matter, this research aims to know and analyze authority and responsibility of Notary / PPAT in signing letter of transfer of right of land and / or building, and juridical implication of Notary / PPAT signature in the statement letter. The research method used by the writer is the statutory approach. Notary I PPAT does not need to be involved in the Letter of Declaration of the transfer of land and building rights, and the Notary Law does not mention any applicable sanctions.
\end{abstract}

Key words: Signature, Notary Public, Land Acquisition Official (PPAT), Statement Letter, Land Rights, Sale and Purchase Agreement. 


\section{INTRODUCTION}

An income tax that obtained from a transaction of transfer property in the form of land and / or building (property tax) is regulated under article 4 paragraph 2 letter $\mathrm{d}$ of the act number 36 year 2008 on the fourth amendment of the act number 7 year 1983 concerning the tax income, where the tax is final or by treating the payment of the tax as a repayment of the whole tax requirement on the tax object. Pursuant to article 1 paragraph (2) on the Government Regulation Number 71 Year 2008 on The Third Amendment Of The Government Regulation of Republic of Indonesia Number 48 Year 1994 Concerning The Payment of the Tax Income from the Transfer of Rights of a Land and/ Or Building, what it means by the transfer of rights of a land or buildings are :

a. Selling, exchange, an agreement of transfer of rights, release of rights, handover of a rights, auction, grant or other way which agreed upon the other parties other than a government.

b. Selling, exchange, an agreement of transfer of rights, release of rights, handover of a rights, auction, grant or other way which agreed with the government in terms of the establishment of development for the public interest that does not need a particular requirement.

c. Selling, exchange, an agreement of transfer of rights, release of rights, handover of a rights, auction, grant or other way which agreed with the the government in terms of the establishment of development for the public interest which need a particular requirement.

Today, the object of income tax on the transfer of rights of a land have expanded, it is not only a transfer of rights of a land or building which proven by making a deed of sale and purchase, it includes a transaction of transfer of rights which still in the form of binding agreement of sale and purchase. According to article 1 paragraph 2 of government regulation number 34 year 2016 concerning tax income of the income from a transfer of rights of a land and/or building, and bonding agreement of sale and purchase of a land and/or building as well as its amendment mentioned that what it means of a taxable incomes are:

a. An income from a transfer of rights of a land and/or building as mentioned on paragraph 1 letter a is an income that accepted or obtained by a party who transfers a rights of a land and/or building through selling, exchange, releasing rights, transfer of rights, auction, grant, inheritance or other way which agreed upon the parties.

b. an income from bonding agreement of sale and purchase of a land and/or building as well as its amendment as mentioned on paragraph 1 letter $b$ is an income from: (a). seller which his name listed on the binding agreement of sale and purchase at the first time of signed; or (b). a buyer which his name is listed on the binding agreement of sale and purchase before the amendment or addendum of the binding agreement of sale and purchase, on the amendment of the buyer parties on the binding agreement .

The provision above provide an understanding that every transaction on transfer of rights of a land and/or building is an object of income tax. Every transaction which taxable by accordance to article 4 paragraph 2 is count based on the final tariff which has been determined multiplied by the transaction value as a tax base. The calculation of this tax, frequently making the tax payer objected to pay as a consequences of the high amount of the payment. The transfer of rights of a land and or building often done by the law subject because the increasing of needs or because of financial difficulties, further it arise an action to do transfer of rights which sometimes not necessarily profitable. This matters often creates a motivation for the seller particularly to avoiding or smuggling the tax.

By virtue of article 2 of tax regulation of director general number PER-18/PJ/2017 concerning the research procedures on the proof of compliance the income tax of income from transfer of rights to land/ or buildings and agreement on binding of sale and purchase 
of land and/or buildings along with the amendments, stated that the research is done whether formally or materially, further, article 3 of the same regulation required that particularly for the formal research, the tax payer or his attorney must delivered the form of the proof research of tax fulfillment of income tax by attached tax payment slip that has been numbered as a state revenue number, the statement letter of transfer of a land and/ or building that has been filled completely and stamped, the photocopy of the whole sale and / or the proof of cash payment that has been signed by the party who transferred the rights of a land and/ or building, and several addition administration requirement.

The responsibility on the materiel proof of the statement letter cause an anxious to the notary and official land deed, concerning the existence of sanctions for the notary or official land deed if they don't fulfil the provisions. ${ }^{1}$ The writer sees there are ambiguity on the interpretation of article 3 of the regulation of general director number PER-18/PJ/2017 concerning the research procedures of evidence on fulfillment of deposit obligations of the income tax on income of transfer of rights of a land and/ or buildings and the bound agreement on sale and purchase of a land and/ or buildings along with the amendment, including attachment II of this regulation particularly concerning the demand of notary or official of a land deed signature, including the binding agreement of sale and purchase as well as the amendment.

According the background of study above, the problem arises on this research is whether the authority of a notary/ official land deed (PPAT) along to signed and acknowledge the statement letter of the transfer of rights of a land and/ or buildings as attached on the attachment number II of regulation of tax general director number PER-18/PJ/2017 concerning the research procedures of evidence of fulfillment deposit obligation of income tax on the income of transfer of rights of a land and/ or buildings along with the amendment may be considers take responsibility? What is the juridical implications of a notary/official land deed signature on the statement letter of transfer of rights of a land and/ or builidngs or the transformation of binding agreement of sale and purchase of a land and/or buildings?

The research method of this journal is a juridical normative juridical research which is through analyzing the articles, principles and doctrines that often used by the legal expert ${ }^{2}$ concerning the problem research which is the signature of a notary/official land deed on the statement letter of transfer of a rights of a land and or buildings or the transformation of binding agreement on sale and purchase of a land and/or building.

The research is about the norms on the regulation tax director general number PER-18/ $\mathrm{PJ} / 2017$ concerning the research procedures of evidence on fulfillment the deposit obligation of tax income of the income of transfer rights of a land and the binding agreement of sale and purchase along with the amendment which linked with the act number 30 of 2004 on the notary official as amended with the act number 2 of 2014 on the amendment of act number 30 of 2004 on the notary official

The approaching concept is by using the legal approach (statute approacl), in order to find the definition of legislation then analyzing the regulation ${ }^{3}$ which linked with the juridical implications of notary/ official land deed signature on the statement letter of transfer of rights of a land and/ or buildings or the amendment of binding agreement of sale and purchase of a land and/or buildings in accordance with the attachment II of regulation of tax director general

\footnotetext{
${ }^{1}$ Permana Y.S,Salim Hs, A.Munandar. (2017). Responsibility Of The Notary In The Depository Of Land Ownership Certificate Within A Graduallyselling-Purchasing Alliance. Jurnal IUS Kajian Hukum dan Keadilan, 5(3), 448-462.

${ }^{2}$ Pertiwi, E. (2018). The Notary Responsibility on Nominee Deed Which Contain Against The Law Actions By The Parties. Jurnal IUS Kajian Hukum dan Keadilan, 6(2), 245-258.

${ }^{3}$ Ahmad Laduni Arif Rahman and Rusdianto Sesung.(2017). The Authority of the Honorary Regional Notary Assembly in Relating to Inspection of Notary of Move of Position Area by Law Enforcement Officer, Unram Law Review Volume 1, Issue 2 October 2017, page 4.
} 
number PER-18/PJ/2017, so that it may be find the legal certainty concerning an authority as well as a responsibility of a notary/ official land deed on signing including the sanctions.

\section{ANALYSIS AND DISCUSSION}

\section{The Statement Letter Of Transfer Of Rights Of A Land And/ Or Buildings As Evidence}

The statement letter of transfer of rights of a land and/or buildings as attached on the attachment II of tax general director regulation number PER-18/PJ/2017 concerning the research procedures of evidence on fulfillment of obligations for depositing income taxes from the transfer of rights of a land and/ or buildings, and a bonding agreement of sale and purchase of land and/ or building and its amendments (further called as a statement letter of transfer of rights of a land and/ or buildings), basically as a statement which made by the selling parties together with the buyer in an agreement of transfer of rights of a land and/ or buidings in means to satisfy the administration requirement for a formal research on the evidence of fulfillment obligations of income taxes deposit.

Further, if the submission of this formal evidence completed or suitable with the regulation then the local tax office will issues a formal research certificate proof of fulfillment of tax deposit (article 4 paragraph 2 of PPH) as a basic rules for a notary and/ or official land deed to signed the deed of transfer of rights of a land and/ or buildings.

Furthermore, the writer able to explain that a statement certificate of rights of a land and/ or building that stated on this research, having several evidence power such as :

\section{An Evidence Of Issues Of Statement Letter As Private Deed (Uitendige Bewijskracth)}

According to article 1876 of civil book stated that someone who is forwarded a private deed is required to admit or deny his signed. While for a heir enough with explaines that he does not recognize the sign or writing. ${ }^{4}$ if those sign denied by the heirs, according to article 1877 stated that the deed must be examined in the court. ${ }^{5}$

The strength on issue evidence is an evience strength which based on the condition of the deed issues, it means that a certificate which look like a deed, must be recognize as a deed until it proofs otherwise. Different from an authentic deed which made in front of the official, where the sign of the official rules as authentic guarantee of the deed, so that it has the strength of birth evidence, then a private deed does not have the strength of birth evidence. It is means that a private deed only legally applicable if someone who signed it recognizing the truth of his signature.

\section{The strength of formil evidence of statement certificate as private deed (Formiil Bewijsk- racth)}

The strength of formil evidence from the deed may be proven that everything which stated and listed on the deed is true as a will of the parties in the deed. Moreover, someone who signed is considers right on explaining the things in the deed.

The strength of private deed power is not absolute, because its formil strength was not made in front of the general official. Therefore, the explanation which listed cannot be recognized the truth. Because the content and the information which listed in the private deed uncertain as a conformity of the parties explanation. A private deed has a strong formal evidence if the

\footnotetext{
${ }^{4}$ Article 1876 civil book, " whoever who faced with a private writing by a person who file a lawsuit into him, is required to recognizing or denying his signature explicitly, however for his heirs or a person who gain a rights from him, it is enough for them to explain that they did not recignizingg the signature or writing as a writing or signature from a person they represented"

${ }^{5}$ Pasal 1877 KUHPerdata, "if someone denying a writing or his signature, or even if the heirs or the person who gain a rights from it did not recognize it, then athe judge must give an instruction so that the truth of writing or signature must be investigated in front of the court”.
} 
signature of the private deed is not denied. It means, someone who sign considers rights stated the content of the deed. As long as the originality of the signature in the deed recognizes of the maker, then the strength of this formal evidence of the private deed is the same as the strength of formal evidence from authentic deed.

\section{The strength of material evidence of statement certificate as a private deed (Materiele Bewijskarcht).}

Concerning the civil proof, a private deed for a judge is a free evidence (Vrij Bewijs) since a private deed only has a material evidence strength after it is proved the strength of formil evidence. According to article 2 of tax general director regulation number PER-18/PJ/2017 stated that:

"the research of tax fulfillment evidence of income tax deposit as stated under article 1 involved the formal and material research"

Further, it is affirmed under article 6 of tax general director regulation number PER-18/ $\mathrm{PJ} / 2017$ that :

"in order to ensure the truth of the amount of tax payable, the tax office do some material research after the formil information research certificate of income tax fulfillment evidence as stated under article 4 paragraph 2 issued".

This material research is a $n$ effort to ensure the truth of the certificate of transfer of rights of a land and/ or building in accordance with the information which provided by the parties. It means this statement certificate has an evidence strength as appropriate as a deed, it provides a certainty on the event that the parties did or implemented as listed on the deed, which is concerning the occurrence of sale and purchase of a land and/or builidngs after the payment of the income taxes.

According to the discussion above then the writer views that a statement certificate of transfer of rights of a land and/ or building as means on the attachment II of general director regulation number PER-18/PJ/2017 may be applicable as a private deed. It means that the statement letter may become as a proof according to its content, eventhough basicly it has the unperfect evidence power if its linked with the other party which may be able to proof contrary which is the content of the statement is not right. Other than that, the private deed may become a complete evidence as long as the signature of the certificate is recognized the originality whilst if the signateure or writing denied, then the falses examination process of its originality must be solved first.

\section{The Authority of a Notary to Take Part in Signing and Acknowledge of the Transfer of Rights of a Land and/ or Buildings Statement Certificate}

As discussed on the introduction, that in transfer of rights of a land/ or buildings, the seller as a taxpayer or his attorniey must submit a request of the fulfillment of income tax evidence research by attaching the tax payment resit which has stated the transaction number of state revenue, the statement certificate of transfer of rights of a land and or building which already filled completely and stamped, the photocopy of all sale proof and/ or evidence of cash money acceptance which has been signed by the party who transfer the rights of a land and/ or buildings and several addition administration requirement. However, the problem is a notary who is not a party in this legal action, demanded to take part in signing and stated that a notary also acknowledge the statement certificate of transfer of rights of a land/ or buildings that already filled completely and stamped. This matters a bit confusing since a notary only an official who 
should be only enough in signing deeds of transfer of rights of a land/ or building whether it in form of bonding agreement deed or sale and purchase deed. ${ }^{6}$

The description of article 15 of notary official act concerning a notary authority above explained that in signing and acknowledge the statement certificate of transfer of rights of a land/ or buildings is not an authority of a notary. According to article 15 of notary official act have stated in detail concerning the authority of a notary attributively.

No attributive authority provide a way for notary to acknowledge and signing a statement letter which particularly become a fulfillment proof of income tax payment. Basicly, a notary authorized to make an authentic deed on the action, agreement and determination which required by the regulation and/ or required by the one who concerned to be stated on the authentic deed or other authority under the act of notary official. While the statement certificate of transfer of rights of a land and/ or buildings don't fulfill the formula of authentic deed as regulated under notary official act or even article 1868 of civil book. The statement certificate as attached II of general director regulation number PER-18/PJ/2017 is only in the form of letter which considers as a private deed, since the purpose on making the statement certificate is as an evidence of fulfillment the income tax payment from a transfer of rights of a land which will be use on the importance of formal research evidence and outwardly this statement certificate is not made by or in front of a notary.

Actually, the obligations on taxes, particularly an income taxes (Pph Article 4 paragraph 2 of income tax act) is a personal responsibility from the pax payer. This is as a consequences from self assessment system which followed by the state of Republic of Indonesia which is a tax collection which provide an authority for the tax payer to determines of the tax amount payable.

An income tax of transfer of rights of a land and/ or building is a subjective tax. It means that this tax worn to them who already satisfy the criteria as a tax payer such as regulated under tax regulation, whether in form of individual or legal entity. The income tax which worn to the individual or legal entity who accept or gain an income from transfer of rights of a land and/ or building is obliged to pay his income tax payable or cut off by the buyer who acted as a cutter of income tax which appointed by the tax general director. ${ }^{7}$

Through the description above, it become clear that a notary or official land deed is not necessary to be included in the statement certificate of transfer of rights of a land and/ or building, as a whole it become absolute as a responsibility of the tax payer.

The writer opinion, the whole truth from statement of tax payer should become an absolute responsibility for the tax payer (as a consequences from self assessment system) which is a form of his obedience of his tax obligation. On the other hand, a notary or official land deed is not a party in the transfer of rights of a land and/ or building. Moreover, the statement certificate is not an authentic evidence concerning the legal action of sale and purchase law of

\footnotetext{
${ }^{6}$ Article 5 of general director regulation number PER-18/PJ/2017 concerning the procedures on research of income tax obligation of the transfer of rights of a land and/ or building, and bonding agreement of sale and purchase of a land and/ or building as well as the amendment. " an authority official may sign a deed, decision, agreement or minutes of auction on transfer of rights of a land/ or building after the formal research of information letter of fulfillment evidence of income tax payment as mention under article 4 paragraph 2 issued”.

Article 3 of government regulation of republic of Indonesia number 34 year 2016 concerning income tax from transfer of rights of a land and/ or building, and bonding agreement of sale and purchase of a land and/ or building including its amendment.

“ a person or entity who accept or gain an income from transfer of rights of a land and/ or building as meantion under article 1 paragraph 1 letter a, is required to deposit an income tax payment as mention under article 2 paragraph 1 letter a and letter $b$ to the bank/ post office perception before the deed, decision, agreement or minutes of auction of transfer of rights of a land and/ or building signed by the authority official”.
} 
a land and/ or buildings. Its very risky for a notary or official land deed to stated, acknowledge or signing a statement certificate. A notary and/ or official land deed only recorded the will of the parties in transfer of rights of a land and/ or building. There is no obligations for a notary or official land deed to prove the material truth from legal action which done by the parties. ${ }^{8}$

\section{The Juridical Implication Of Notary Or Official Land Deed Signatures On The Statement Certificate Of Transfer Of Rights Of A Land And/ Or Building}

According to the act number 36 year 2008 concerning income taxes, under article 1 stated that an income tax worn to the tax subject on income he obtained in year of taxes. One of it is income tax, article 4 paragraph 2 is final, including an income from transfer of property transactions in the form of land and/ or building which regulated according to the government regulation number 34 year 2016 concerning the income taxes of transfer of rights of a land and/ or buildings and the agreement of sale and purchase of a land and/ or buildings including the amendment, stated that:

“ an individual or entity who receives or obtaines an income from transfer of rights of a land and/ or buildings as means under article 11 paragraph 1 letter a, is required to pay himself his income tax payable as mentioned under article 2 paragraph 1 letter $a$ and $b$ to the bank/post perception before the deed, decision, agreement or minutes of auction of transfer of rights of a land and/ or buildings signed by the official authority."

The problems arises when the parties information (which is the statement certificate of transfer of rights of a land and/ or building which made by the seller and buyer on land sale and purchase) concerning the transaction nominal is rejected/ not recognize the truth by the tax office, so that it causes on not validated the income tax. For a notary or official land deed, this matters turn the official cannot sign the deed, decision, agreement or minutes of auction of transfer of rights of a land and/ or building. Of course, this matter will detain the process transfer of rights of a land and/ or buildings.

An individual or entity who have fulfilled the obligation on income tax payment from the transfer of rights of a land and/ or building or the change of bonding agreement of sale and purchase of a land and/ or building. The application letter must be sign by the seller and buyer also the notary or official land deed.

\section{A Statement Of "Knowing" And Signature Of A Notary/ Official Land Deed On The Statement Certificate Of Transfer Of Rights Of A Land And/ Or Building Under Perspec- tive Of Tax Criminal Action}

The tax office on the examination of suspected tax crime in asking of information from a notary or official land deed of who concerned as regulated under article 35 paragraph 1 of the act number 6 of 1983 on the general provision and procedures of taxes as amended lastly with the act number 16 year 2009 (further called KUP) as follows:

"when running the tax regulation it is need the information or proof from the bank, public accountant, notary, tax consultant, administration office, and/ or other third party, who has the relation with the tax payer or investigator of criminal action on the taxes field, according to written request from tax general director, those parties are required to give an information or proof which requested"

Concerning the information which will be given on the transaction of transfer of rights of a land and/ or building, then it is not separated from a statement of "knowing" and signature

\footnotetext{
${ }^{8}$ This matteras stated in the republic of indonesia suprme court decision number $702 \mathrm{~K} /$ Sip/1973 sept 51973 which is “ a notary function only to record/writing the matter which desired and stated by the parties who face the notary, there is no obligation for a notary to investigate materially of the matter which stated by the facer in front of the notary”
} 
of a notary or official land deed on the statement certificate which attached as a completion of formal evidence by the tax payer. The definition of "knowing" under dutch term used a "gezein" term, which means "seen", gezein, en accoor bevonden means see and approved, under Indonesian language (bahasa) generally using " knowing” not "seen” as a translation from gezein. So, the one who "knowing" can be shortly understand as " understand and take responsibility of the whole truth on the statement certificate, the event, the contents and the signature even the date. If the definition of "knowing" which signed by a notary or official land deed on the statement certificate it means take a part on responsibility of the whole statement, then this matter precisely endanger the position of a notary or official land deed. It is means, a notary or official land deed, basicly only recording the will of the parties on transfer of rights of a land and/ or building and there is no obligation for both of them to prove materially concerning the truth of information which given by the parties particularly on transaction price which agreed by the seller and buyer.

The involvement of a notary on legal cases caused by the mistake on the deed which he made, whether it is his own mistake or a mistake by the parties or one of the parties who is not provides an information or the real document ( there is no good will from the parties or one of the party). The writer opinion that if a notary or official land deed stated "knowing" on the statement letter which made by the tax obligator, while the content of the statement known and may be approved materially evidently is not in accordance with the real conditions, then without realized it it already open a space for himself to be included on the criminal action which is take a part on helping provide a false information. ${ }^{9}$ Eventhough, a notary basicly is not able to be asked for a criminal responsibility, because a notary only have responsibility on the formal side on making the deed. ${ }^{10}$

The action of a notary or official land deed who take part on signing the statement certificate of transfer of rights of a land and/ or building which able to be proved materially indicated criminal by the tax office may be view the link on article 39 and 43 of criminal code as well as article 55 of the code. Article 39 of the criminal code descripted that an action of provides false information (reporting the transaction price which is lower than it should be) is a tax criminal action. Article 43 of criminal code added that the provision of article 39 also applicable for the representative, attorney or the staff form the tax obligator, which is comprehensively take a part on doing, recommending, or helping to commit the crime on taxes.

The writer sees that from the point of view of Indonesian leal system, the matter which mentioned in article 39 paragraph 1 letter $d$ of criminal code is the forgery of something and also one of the form of criminal act which has been regulated under criminal code, the provision on take a part and helping to commit may be seen on article 55 (take a part on..) and article 56 (helping to commit on.. ). ${ }^{11}$ A notary or official land deed may be on position of both sides of this legal action. the involvement of a notary of official land deed on this matter is because there is already an agreement between a notary or official land deed with the tax obligator which causes a loss to the state then it is able to disqualified on taking a part to do a

\footnotetext{
${ }^{9}$ Article 43 of the act number 6 year 1983 concerning the general provision of tax procedures as amended for several times lastly with the act number 16 year 2009. A provision which listed on article 38 and 39, also applicable for a representative, attorney or employee of the tax payer, who thoroughly carry out, take part on carry out, who suggesting or helping commit a criminal action on taxes.

${ }^{10}$ Pieter Latumaten. (2009). Kebatalan dan Degredasi Kekuatan Bukti Akta Notaris Serta Model Aktanya, Makalah yang disampaikan pada Kongres XX Ikatan Notaris Indonesia di Surabaya.

${ }^{11}$ Article 55 of the criminal code : 1) punished as a person who commit a crime: 1e. a person who commit, thoroughly commited or take part on commit the action; 2e. a person with a reward, agreement, abuse of power or influence, violence, threat or deception or by provide a chance, deception or information, in purpose to suggest an action. 2) concerning the people according ti sub 2e above which responsibilited on him only an action that done by purpose to persuade by them, also with the consequences. Article 56 of the criminal code : punished as a person who help n commit a crime: 1) any person who in purpose to help a criminal crime; 2)any person who in purpose to provide a chance, effort or information to commit the crime.
} 
criminal action. While, concerning article 56 of criminal code, R. Soesilo stated that a person who helping on doing.." if he is on purpose to provide an assistance, at the time or before the crime was committed. On the explanation of article 56 stated that the element of " on purpose" must be exist, so that a person who is by chance not knowing have provide a chance, an effort, or information to commit the crime is not punished. The purpose on coomit the crime must be come from the one who given assistance, a chance, an effort or the information. If the purpose arising from the person who give assistance, then this person is in fault on commit " persuade to commit.." (uitlokking). On other definition, if the commit on making a false statement only done by the tax obligator himself without acknowledgment by a notary or official land deed, it may be concluded that there is no purpose from this officials then it should not be punished as a criminal action.

So that, the writer opinion that it should not be wheteher for a notary or official land deed does not need to stated on "knowing and signing the statemet certificate of transfer of rights of a land and/ or building.

\section{CONCLUSION}

Basicly a notary or offciail land deed is not necessary to be involved on the statement certificate of transfer of rights of a land and/ or building, the whole is absolutely become the responsivility of the tax obligator. The tax system which applicable in Indonesia is a self assessment system which provides an authority the tax obligator to counting, submitting and reporting himself the fulfillment of his tax obligaton, particularly on the final tax income of article 4 paragraph 2 letter $\mathrm{d}$, so that the tax obligator have a full responsibility on the truth of content of the statement or information he made.

Whteher the act of notary official or the official land deed does not regulated the authority of both officials on providing a statement of "knowing and signing the statement certificate of transfer of rights of a land and/ or building, so that the action which means on attachment II of the general director regulation number PER-18/PJ/2017 do not have a $n$ adequate a legal basis.

The act of notary official does not stated the criminal sanctions however on a legal action must be done by a notary if its contains elements of forgery of the purpose on his official duty where the information or contents is false then a notary may be sanctioned of criminal sanction, even an administrative sanctions according to the notary official act and code ethic of a notary. So is the case with official land deed may be sanctioned of criminal sanctions under perspective of criminal taxes action.

\section{BIBLIOGRAPHY}

\section{Book}

Pieter Latumaten, (2009). Kebatalan dan Degredasi Kekuatan Bukti Akta Notaris SertaModel Aktanya,Makalah yang disampaikan pada Kongres XX IkatanNotaris Indonesia di Surabaya.

\section{Journal Articles}

Ahmad Laduni Arif Rahman and Rusdianto Sesung, (2017). The Authority of the Honorary Regional Notary Assembly in Relating to Inspection of Notary of Move of Position Area by Law Enforcement Officer, Unram Law Review Volume 1, Issue 2 October 2017.

Permana Y.S,Salim Hs, A.Munandar, (2017). Responsibility Of The Notary In The Depository Of Land Ownership Certificate Within A Graduallyselling-Purchasing Alliance. Jurnal 
IUS Kajian Hukum dan Keadilan, 5(3), 448-462.

Pertiwi, E., (2018). The Notary Responsibility on Nominee Deed Which Contain Against The Law Actions By The Parties. Jurnal IUS Kajian Hukum dan Keadilan, 6(2), 245-258.

\section{Laws and Regulations}

Kitab Undang-Undang Hukum Perdata.

KitabUndang-Undang Hukum Pidana.

Undang-Undang Nomor 6 Tahun 1983 tentang Ketentuan Umum dan Tata Cara Perpajakan, Lembaran Negara Republik Indonesia Nomor 49 Tahun 1983, Tambahan Lembaran Negara Republik Indonesia Nomor 3262.

Undang-UndangNomor 7 Tahun 1983 tentang Pajak Penghasilan, Lembaran Negara Republik Indonesia Nomor 50 Tahun 1983, Tambahan Lembaran Negara Republik Indonesia Nomor 3263.

Undang-UndangNomor 30 Tahun 2004 tentang Jabatan Notaris, Lembaran Negara Republik Indonesia Tahun 2004 Nomor 117, TambahanLembaran Negara Republik Indonesia Nomor 4432.

Undang-Undang Nomor 36 Tahun 2008 tentang Perubahan Keempat Atas Undang-Undang Nomor 7 Tahun 1983 tentang Pajak Penghasilan, Lembaran Negara Republik Indonesia Tahun 2008 Nomor 133, Tambahan Lembaran Negara Republik Indonesia Nomor 4893.

Undang-UndangNomor 16 tahun 2009 tentang Penetapan Peraturan Pemerintah Pengganti Undang-Undang Nomor 5 Tahun 2008 tentang Perubahan Keempat Atas UndangUndang Nomor 6 Tahun 1983 tentang Ketentuan Umum dan Tata Cara Perpajakan Menjadi Undang-Undang, Lembaran Negara Republik Indonesia Tahun 2009 Nomor 62, TambahanLembaran Negara Republik Indonesia Nomor 4999.

Undang-Undang Nomor 2 Tahun 2014 tentang Perubahan Atas Undang-Undang Nomor 30 Tahun 2004 tentang Jabatan Notaris, Lembaran Negara Republik Indonesia Tahun 2013 Nomor 232, TambahanLembaran Negara Republik Indonesia Nomor 5475.

Peraturan Pemerintah Nomor 71 Tahun 2008 tentang Perubahan Ketiga Atas Peraturan Pemerintah Republik Indonesia Nomor 48 tahun 1994 tentang Pembayaran Pajak Penghasilan Atas Penghasilan Dari Pengalihan Hak Atas Tanah dan Atau Bangunan, Lembaran Negara Republik Indonesia Nomor 164 Tahun 2008, Tambahan Lembaran Negara Republik Indonesia Nomor 4914.

Peraturan `Pemerintah Nomor 34 Tahun 2016 tentang Pajak Penghasilan atas Penghasilan dari Pengalihan Hak Atas Tanah dan/atau Bangunan, dan Perjanjian Pengikatan Jual Beli atas Tanah dan/atau Bangunan Beserta Perubahannya, Lembaran Negara Republik Indonesia Nomor 168 Tahun 2016, Tambahan Lembaran Negara Republik Indonesia Nomor 59

Peraturan Dirjen Pajak Nomor PER-18/PJ/2017 tentang Tata Cara Penelitian Bukti Pemenuhan Kewajiban Penyetoran Pajak Penghasilan Atas Penghasilan dari Pengalihan Hak Atas Tanah dan / atau Bnagunan, dan Perjanjian Pengikatan Jual Beli Atas Tanah dan/atau Bangunan Beserta Perubahannya.

Putusan Mahkamah Agung RI Nomor: 702 K/Sip/1973, 5 September 1973. 